\title{
OVERVIEW: STRUGGLE FOR ISLAMIC EMIRATE OF AFGHANISTAN
}

\author{
Naseem Akhtar \\ Department of Political Science \\ University of Balochistan \\ Quetta-Pakistan \\ Zemali455@gmail.com \\ Dr. Abdul Qadeer Khan \\ Department of Political Science \\ University of Balochistan \\ Quetta-Pakistan \\ Qadir.uob62@yahoo.com
}

\begin{abstract}
Afghan history evident mostly, war and battles, ranging from civil wars to international forces, Taliban came in power after the withdrawal of soviet forces. Destruction of world trade center proved way for US lead international forces to root Taliban, who were seated in Afghanistan and pushed them out of power, in 2001 this defeat could not be proved to be ultimate. Taliban insurgency caused a number of national and international concern for--- of the Taliban must ruined the women education and participation in all the sphere of life A number of international organization and NGOs examined the pathetic situation of female education in the country, this study emphasis and accessed the efforts of changing scenarios of powers and government and the center and context of Taliban and warriors groups.on the basis of the available result of interviews taken by the different international bodies found its roots in al-Qaeda.
\end{abstract}

On different occasion and different instances were adopted by the Taliban about the implementation and interpretation of Islamic law previously, girls schooling. The facts found different view pointed many Taliban commander was not only their because of their religious extremes approaches but the tribal condition and restriction, contributed to intensified the situation despite on the effort of USA and allies, Taliban adopted the strategy to participate to government physical presence in the state. Wherever they got power. They prolonged the agitation by adopted 


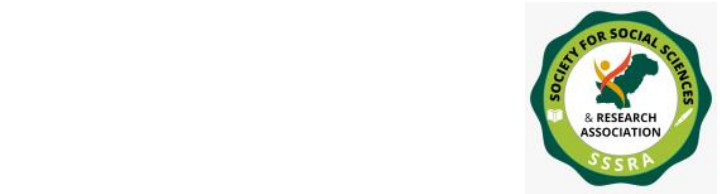

Pak. Journal of Int'L Affairs, Vol 4, Issue 3 (2021)

Overview: Struggle for Islamic Emirate ...

the gorilla war.it completed the international forces to lose the patience China had it's over strategy aiming at constitutional its boarder in the wakhan, ultimately the Taliban announce the Islamic emirate of Afghanistan after leaving number of US forces. A large number of Afghanis seeking refuge in different countries. Taliban could not so far achieving the confidence of their people which will rise new challenge for establishment of a strong state and sound government, while the long duration of wars destroyed the infrastructure completely.

Keywords: Afghanistan, Taliban Insurgency, Female Education Power, Warrior Groups, Al-Quaeda.

\section{INTRODUCTION}

Overall struggle of Taliban for their state is being tried to dig in this article. How strategically they fought and get in spotlight among the essential components of overzealous Islamist are 1. Vital to define fundamentalism's venture to fetch the Muslims to the doctrine known as Al Quran and Al Sunnah. 2. The concept interpreted by the Western critics as radicalism and Islamism and ignore the harmonious organization like Jamiat ul Tabligh seated in Pakistan. Secondly Jihad a Political effort (a previous war) to check the opponent of Islam of even the modern Muslim rulers. The study is wider than merely. These two elements. The south Asia media denotes "Jihadies" as warriors as deep relation between the movements are run by the Extremist Muslims in the two neighboring countries Pakistan and Afghanistan while the Shia extremist segments in Afghanistan are linked with train. Thus the flow of influence to have the continued from outside to inside Afghanistan. It was always claimed by the western the "Khorana" brotherhood movement known as Afghani Islamist Sunni movement supervised from Pakistan. So the type of affiliation established between Afghan Taliban and their supporters is fundamentally Taliban worked with alignment of strategy and logical set up some U.S critics kept believe that the undermining the potential of Taliban may prove adversary. Quiet contrary to the Taliban design, the Taliban's struggle aiming at Islamic state.

An elevation of religious personalities as political leaders is the very basis of the movement. In the comparison of 1905, Taliban from the beginning of the present century the seek the support of these who are opposed the foreign occupation (U.S and allies) are warned towards the establishment of an Islamic Emirate the acknowledged fact by the foreign observers that the Taliban fought not only against the IC but also against the afghan state government at the same time. The organization fought against the Soviet aggression, known as the Hezb-e-Islam acquired more influence over the local especially, 


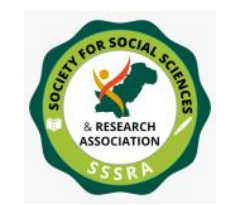

Pak. Journal of Int'L Affairs, Vol 4, Issue 3 (2021)

Overview: Struggle for Islamic Emirate ...

in the North where they could recruit the fighters from non - afghan community. Further they had the commanders with remarkably quality proved themselves strong enough even to demonstrate revolts against, but even these facts could not convince the Westerns to require them strong enough and logical. The efficiency based on centralization and energizing but still adaptable to the local requirements. The vigorous quality, Maulana Haqqani Shawad during the war against Soviet occupation. He earned great fame and respect especially in the early provinces even then the Taliban network is larger and the Haqqani network is beyond their influence. He either couldn't appoint the warriors in his own and here not any separate war plan. The summit between the Taliban leaders and the Haqqani belonged from the same Madrasa. No signs were evidence that Haqqani had any desire to elevate his status as Taliban leader. Taliban's strength element is guerrilla warfare. Among other factors the Taliban are not disintegrated or demented. There is no internal rivalries or any rat race. On contrary they organized their administration of province and districts very well. This situation discouraged the possibilities of crepting to other countries of regional foreign force to create any gulf seat among them. Some commander who were against the central 'Shura' could be helpful but IC unintentionally caused their ball. A few out of killed were Akhtar Osmani, Mullah Beradar and Mullah Dadullah during the first decade of this contrary in Dec 2006, August 2007 and May 2007 respectively.

The second character of Taliban was testified through many tests including the killing of their most effective commanders. They recognized again as their political strategy designed for the purpose. Heavy losses lives in 2005, at Arghanzab valley, even, failed to check them. Their forces proved the professionalism criteria. Although the historical background of the region is rich in bravery and fight but, apart all, that is not comparable with the war style of the Taliban due to the abiliting of the Guerilla war style. They organized very multiple attacks. They pushed back the Britain soldiers in 2006 in Helmand. It was shocking for the Britain's as they themselves have a history of war winning against a large number of world nations. The success of acquiring latest equipment multiply their confidence along with their strong commitment with their Islamic ideal ology. The mainly appointments of their Warriors were appointed from the South and East region. The continuous war enabled them to keep training of fresh fighter from the public. To mend the view pointed of the masses in Afghanistan, they adopted the use of media like radio, videos and secret letters. Not only has this but Taliban used the websites on internet. Among the most alarming videos the takeover NATO in Khyber Agency in 2008 and French contingent ambush in August 2008. It is same how rooted in the intense complain in the favor of 'Jihad' (Holy war) against the foreign occupation. For enhancement of the propaganda, the Taliban kept an eye on their state media. They used the modern media more skillfully. 


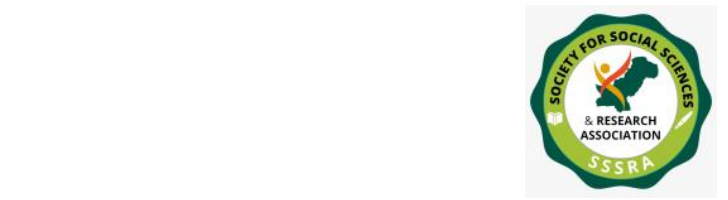

The afghan history saturated with the battles and wars, but since the intervention of Russia in 1972 remained the subject to extra ordinary bloat shed. This study is to throw light concisely to the history of it and from 1970s Between Afghanistan and Pakistan Durand line gives the status to the contrary with less defined boundary. It blocked the way of friendly relations between both of the states on one side and on the other side intensify the ethnic issue in Pakistan.

Mostly its borders were fixed by the clashes and struggle which gives it similarity to the smaller European countries. The history of Afghanistan is identical to the smaller countries in Europe. Afghans resisted foreigner's occupation, there conflicts were mostly from religious angle. They faced downfalls, tussles among the tribes and conflicts for the succession to the thorn. Thus in the regions the Afghans faced challenges more than any other country. Despite the fact that the contrary is older than its surrounding countries. For example more or less it is two hundred years older than Pakistan and more than that from the neighboring states in Central Asia, got their freedom from Soviet Union in 1991. Even then it is more limited in administrative areas than its actual boundaries. Although the Afghans used to face the ethnic varieties and noticeable tensions and faults among them, but it experienced a separate movement. For the view point of the NATO countries, Afghanistan politically is a complex region. It continued as it kept control the legitimacy on both sides of its boundaries, especially successfully confined the foreign activities in the State. Non-governmental efforts and struggle denoted by the foreigner as terrorism perceived as mindless violence against the 'Civilians'. A debate by Walter Laqueur, gave picture that any achievement, if can be achieved, against the extremist, cannot ensure the complete control over the extremist.

The reason for that is the presence of many other individuals always there having desires for the terrorist activities. This situation minimized the possibilities of success against them. The question focused by the foreigners remained to minimize the number of terrorists and ignored the motivational factors causing as the increasing partial element. In addition to the political scenario with Afghanistan the complete picture cannot be exposed without lightening the truth that the neighbor country 'Pakistan' has the only binding force among the nationalities is the 'Religion'. These similarities between the two countries attract the international attraction and support for the region to meet their own political interests and ends. It generated one more factor that the 'Past Cold War Era' the new political trend is to fight for one's interests on the other hand to prevent the peace and prosperity of their own lands. At this stage when Afghanistan is already subjected to the situation, a question comes to Lime Light that law for Pakistan 


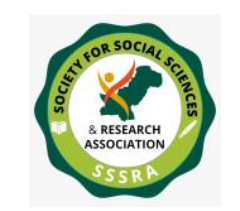

Pak. Journal of Int'L Affairs, Vol 4, Issue 3 (2021)

Overview: Struggle for Islamic Emirate ...

would be successful from keeping aloof itself rising situation to ensure itself as a part of international community.

\section{FINDINGS}

\section{SENTIMENTS OF THE ENEMITY}

The sentiments against the International community (IC) transformed as from 'Mehmaman to Dushman' guest to enemy added further strength to the extremist. These injurious feeling from due to the presence of the foreigners' especially of 10,000 in Kabul, where they lived a luxurious lifestyle. Almost 50\% of the capital city was made 'no go area' for the Afghans. It caused disappointment among them. Further the citizens were compelled to keep thinking that the IC had some secret support and links with Taliban. The opinion was strengthened because of the frequent causalities, arrests, including bomb blasts and damages to the citizens. The 100 prisoners on Bagran Air Base were kept for unlimited time without any charge. They even banned to visit by ICRC. The areas including Lagar province where Taliban are strong targeted by the Special Forces without care of the damages to the innocent citizens. The compensation to the aggrieved families was, in fact an acknowledged of the disaster and increased the amenity and the hatred against the forces, against softening the resentment

\section{LOOPS IN LOCAL GOVERNANCE ADMINISTRATION}

Political splitting administration weaken the control of the Administration weaken the control of the government over the district level. These loops pave the way for insurgency. US from very beginning of this century tried to crush the political force had influence in Afghanistan. The intention behind,that was to eliminate the possible challenging political segment against the President Karzai, who had no political roots in Afghanistan. Karzai kept him dependent upon the people near and dear to him. He filled the important positions of the government on the same basis. The poor selection criteria rebounded the desire of strength. The elimination of the local politicians minimized the choice and selection further. (Carnegie Endowment for International Peace)

\section{GILLES DORRONSORO}

In Afghanistan the Local political leadership remained less effect during recent years. Their meager influence has any remarkable expand. For example Ismail Khan in some parts of Herat province, Ustad Ata in Jawzjan, Ustad Rabbani an area of Badakhshan Province and Wali Karzai in Kandahar, all are having less influenced 


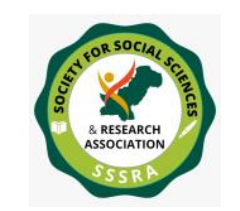

Overview: Struggle for Islamic Emirate ...

personalities. Although a heavy media coverage was supported Gul Agha Shirazi, but still he didn't become strong in Jalabad. His role rather remained as an agent among the local personalities. Even, those who had control over some significant areas, didn't contribute for state structure elevation/strengthen. The central government although rare hence rare tried to improve its role by appointing the local commanders but still it couldn't achieve the state building status. Still the local Leader alike those of 1980s, in their act of taking a ratio of the aid of taking central government of for the international sources, and even use to take share in commerce on both sides of the borders. An effort was made to disarm the people and money was offered them buy their weapon. It provided them an opportunity to buy new one. In fact the venture served them to strengthen their arsenals by new purchase. By 2006, it became clear that in the context of the extremist forces that the IC is not going to continue too far. For the enhancement of the security of their own, the local forces bought quiet large quantity of weapons which led to an increase in South weapons' prices. In the state including the capital city "Kabul" there is no difficulty to by weapon even in any large quantity. All this reflects the lack of security and rule of law. People seek the solution of their disputes in 'Jirga' and to 'Ulema' to get the decisions according to 'Sharia'. Despite all this the military withdrawal of U.S in Afghanistan reveals its failure in the region. Its act to wards table talk with Afghan Taliban proves the acceptance, by the U.S and its allies, for the Taliban as an unavailable force in Afghanistan. It showed the future of the armed action U.S policy in Afghanistan, which cost almost $\$ 144$ billion since the 2001 .

\section{U.S TALIBAN ON TABLE TALK}

On 29'February 2020, an agreement concluded between U.S and the Taliban and clipped with mutual insurance that Taliban would be responsible to prevent Al Qaeda and group alike to use the Afghan land and the U.S would withdraw the armed international troops from Afghanistan by May 2020. Shortly after the agreement, claimed by the U.S official that the Taliban were not acting in accordance with the agreement relating $\mathrm{Al}$ Qaeda and violence increased. The U.S Congress, under the section 1217 of the FY2021. National Defense Authorization Act (NDAA, P.L. 116 283) blamed the administration to put forward report within 90 days verifying the Taliban's steps upholding under the accord on February 2020.

\section{ISLAMIC ORGANISATION WITH GEOGRAPHICALLY TALIBAN'S PRESENCE}

In south Taliban pushed international forces to defensive position and achieved their goals. The different religion based movements were founded during the last century 


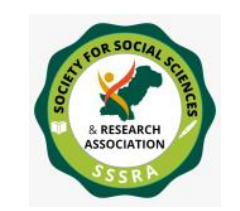

Pak. Journal of Int'L Affairs, Vol 4, Issue 3 (2021)

Overview: Struggle for Islamic Emirate ...

like 'Muslim Brothers' by Hassan Al Banna of Egypt (1906-1949). In Pakistan the names of Abul Ala Maududi. Among Sharias Baqer al Sadr Ali Shariala and Ayaallah Ruhollah Khomeyni. A political Islami party established by Al Maududi has a great influence in South Asia. Neo fundamentalists urge at the implementation of true and actual Islamic practical life with caring the state structure improvement and social issues with the Western view point the conservative religious groups got more active in 1980s as a result the Soviet occupation against Afghanistan and Kashmir, problem too. The revolution of Iran in 1979, engulfed the relations between Shir'as and Sunni and caused the creation of fundamentalist's forces like Afghan Taliban. The groups came on leading positions with Urging 'Jihad' against the West. A member of Arab volunteer rendered their services to these groups in the decade of 1990. The fundamentalism was further boosted up by increasing influence on Saudi authorities on the religious curriculum in Afghanistan and Pakistan. Despite all this the winning strategy of Taliban required to examine from different angles. It was organized in different circumstances when in 1980s. It successfully overcame the political and somehow social issues. It remained adaptable to the changing environment and local needs. As the religious traditional environment tend the people to prefer 'Madrasas' (school based on religious curriculum)instead of government 'school' Saudi's financial support for this remained active. The achievement in 1990s gave clear picture that the Taliban's influence increased effectively in South Western part of Afghanistan. They got control over Herat Boundaries with Iran and 90\% of Afghanistan was went under their control by 1998. The most attention catching aspect of western countries was the strict punishments under their interpretation of Islamic Sharia Law 'Hadood' laws. They adopted, initially strict stand towards the girls schooling and education preferring 'purdah' veil for ten plus of age.

They completely banned cinemas, T.Vs and Music. Those harsh memories compelled the masses to migrate from Afghanistan, after the final victory of Taliban over the entire area of Afghanistan. In 2001, they demolished the statues of famous Bamiya Buddha in central Afghanistan. Claims and blame from the Western countries remained against Pakistan for the support of Taliban on the grounds of the initially Afghan Taliban mostly educated in the Mudrasas in Pakistan. Pakistan is among the three countries who recognized the Taliban at the Eve they were in the power in Afghanistan. However Pakistan constantly denied the claims. The existence of "Quetta Shura" presence of senior members of Taliban in Quetta city of Pakistan claimed by West and refused by Islamabad. Against a huge force, more than ever in the history of the region, Taliban regaining and even extending control over Afghan lands remarkable attack against NATO Camp Basion base was organized and demonstrated. They attacked on Kabul in 2012. In 2013, the Taliban revealed their intention.

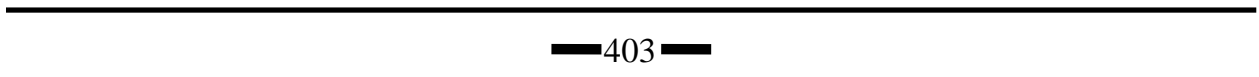




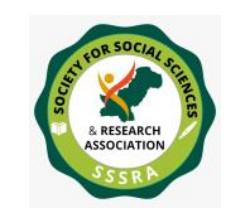

Pak. Journal of Int'L Affairs, Vol 4, Issue 3 (2021)

Overview: Struggle for Islamic Emirate ...

\section{TRANSFORMED STRATEGY}

To open an office at Qatar, but in those days mistrust was high and negotiations remained unfruitful. Mullah Mansour, the deputy of Mullah Omar after his death, was killed in an attack by US in May 2016 and succeeded by his deputy Mawtawi Hibatullah Akhundzada. As a result of the accord in February 2020, Taliban adopted the channel of targeted attacks instead the attacks of previous style. So the agreement could change only the strategy not the goals based on their ideology.

\section{RESULT AND DISCUSION}

\section{LATEST DEVELOPMENTS}

US new President Joe Biden, in April 2021, declared 11 September, as a dead line for the completion of withdrawal process of forces, the eve of competition of twenty year of 9/11 World Trade Centre Collapse. They got control over the country and claimed it as their victory after a war of two decades against super power USA and her allies and ousted them eventually. Not only this but they ultimately acquired control of Kabul and washed off the government of Ashraf Ghani. The same was suspected and predicted by the intelligence resources by the intelligence resources of US that the government would not survive so long after the departure of the US forces the departure of the Us forces on the basis of February 2020, agreement the US troops were required to leave by May, 2021, but Joe Biden extened it pu to $11^{\text {th }}$ September 2021 in his announcement made on 14 April 2021. It caused the resentment of Taliban as the US couldn't abide by their words. They warned that US would be responsible for the consequences. The US indicated to "hit back hard." The new face after the establishment of the Taliban hold in Afghanistan has become the most delegate relating the new political scenario of the whole region. Already the US officials indicated many options including the Afghan government personnel training after the US withdrawal. It alarms the US interests and upcoming plans for the regain even after withdrawal of its forces.

As consequences of the withdrawal of USA from Afghanistan, as assessed by the American officials, may appear in a civil war between the government and groups and can go back to the situation of 1990s. To some extend one of the reasons is the poor governance lack of rule of law the desire for taking land under their control. The issues already damaged the status of the state, particularly, as matter solving authority instead of conflicts boasting. The governors fought for power and it was distributed among them and weakened the state. The fact intensified the need, more than ever before, to fight against the groups to restore stat's power and internet sovereignty. 


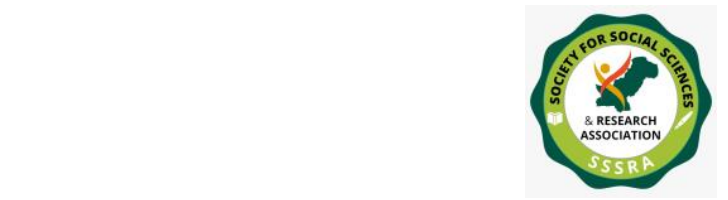

The tale of the agony of the civil society in Afghanistan was examined by AIHRC in a survey and elaborated in its report in post 2001. I consulted many Afghans who evidenced different battles and armed clashes occurred due to the incompetency of the political system since 1979. The changing governments could not improve the system and the people remained, constantly, the target of the bloody conflicts. The post Bonn Agreement period, even, failed to lessen their grievances. The persons responsible for mentionable human rights violation remain to in power. This situation could not bring in development, but entrenched desperation in the people and swallowed the trust between the government and the public. The sentiments of target among masses may result in armed conflicts, were suspected. Relating motivational factors to join rebellion, although, were not founded thoroughly, somehow, these rooted in the deficiency of trust relating justice. Sarah Ladbury's in depth 2009, investigation of the drivers of radicalization in Afghanistan for the UK's Department for International Development (DFID), for 10 AIHRC, A, Call for Justice, P. 17-11.

Afghan's panic caused by the offensive distracted political system, lawlessness and stead of mutiny. Government and corruption contributed $29 \%$ and $17 \%$ to the issue respectively, while insecurity had the status of $42 \%$. With $10 \%$ corruption in administration ranks $6^{\text {th }}$ in Line. Her findings supported the belief in the justice was pushing the people to insurgency. She interviewed not only the common armed persons of Hizb-e-Islami and the findings consolidated the belief in the connecting between the both. Further added that even institutions like police were being pulled towards the extreme due to the circumstances. This extreme disappointment compelled the people to look for some source other than the government and that fact left the option but only being a fighter. Thus the position of Taliban on district and provincial levels constantly. Hens the supporter of Hizb-e-Islami and the Taliban remained increasing. Between the government and the Taliban the people indicated the level of bad governance which paved the way of public flow towards the extremism.

With similar study results, Ledwidge's debate on the basis 500 interviews from six areas throughout the state and find the government unfair and causing the promotion of the extremism. One tribal head in added that the lack of facilities and harsh life conditions are not the actual issue but the absence of the good governance is the core issue. The security statue worsening forces was the expanding gap between the government and people. It's hard to have any single reason as a initially binding factor for individuals but injustice and a lawless use of power may be considered in the reasons for the purpose. The same concept from the Afghans view point discovered by Martine Van Bijlert, exceptionally mentions the word "Naraz" and "Majboor" resented and 


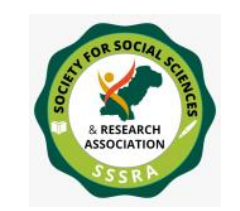

Overview: Struggle for Islamic Emirate ...

pushed, respectively, towards the choice other than the State's obedience. It is because of the pushing and abusing them by the empowered persons. It was done through their expulsion from the government posts and the status of decision makers, they became "naraz". The arrests and their property plundered by the government caused "majboor" abusing them and compelled them. The term "majboor" specified the status of the government as cruel "zalim". She also put her opinion in the context of her finding that they could be return if the reason could be eliminated. M. Van Bilijert, Unruly Commanders and Violent Power Struggles; in A Giustozzi(ed) Decoding the New Taliban: Insights from the Afghanistan Field (New York/Chichester Columbia University Press/Hurst, 2009), p. 160, ibid, p. 161, 6. Venture of stability by 2001, optimized the people's thought relating upcoming peace and stability. They looked for a proper government with the rule of law, but received a corrupt and less independent government, which had no interest in the public benefits. It showed no signs of efficiency. The Taliban availed the chance and expanded their man power and their support too.

Nothing different could be found by Ladbury and observed corruption expanded from favoritism up to taking out of away the national wealth development projects on provincial and district level by the political leaders and they had to appoint armed persons for personal protection.

Another type of inclusion to Taliban is called by Thomas Rutting, an observer in Afghanistan since quite long period. He put that if not a large number but a notable number of people chose to be the part of insurgency because they condemned the path of corruption as government officials, rejected being the part of local government and join Taliban. So she called them "anti-corruption Taliban". The examples of that type "jihadis" were in Southern parts, and one of the leading of "Nurzai" tribe in Urozgan.

A relative of an ex jihadi commander of Taliban told his story of choosing to join the jihadis. He himself was not by nature on their side but the discriminating behavior of Jan Mohammad, an influential of the rival tribe Popalzai. Jan Mohammad was the provincial governor too. He had poppy fields. The same kind of fields had in the ownership of the Nurzai. Jan, by using his post and position eradicated the poppy fields of Nurzai, but didn't his own fields. This act of injustice provoked him to join Taliban. Thus the use of power by the empowered pushed the people towards Taliban and they joined them even unwillingly. So the personal revenge based sentiments led them to do so. All this resulted in the loss of faith in the Americans on one side and on the other side the government officials strengthened the antigovernment groups. Among other factors the economic interests and motivations were prominent. 


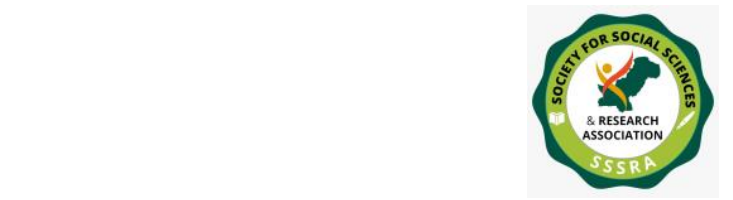

Mostly influential tribal heads indulged in growing and producing drug relating crops as the main source of money making. The rivalry and race in this connection kept insurgency alive even if the jihadis could be controlled, agitation was to remain uncontrolled. Further the funding from outside the shelters may intensify the matter. As far as the question of the role of neighboring countries including Pakistan remained the target of criticism by the western countries and they didn't exempted Iran from being responsible for the issue. If the interference by the foreign states could be eliminated even then the tribal conflict seems endless and in clear words insurgency will remain and flourish. However the tribal contacts across the border may lift the possibility of threat to peace internally. The challenging matter, intensified the need to counter the fighters. It involved a series of security measures and Pakistan spent a remarkable Budget and continuously engaged in the efforts to eradicate the problem. However it can be difficult to sweep off it completely but so far the task couldn't be accomplished. It is a hard challenge and demands tangible steps including a constant development in the social, economic and political sectors, particularly, in the areas influenced by the Taliban. Of course it is not possible for Pakistan without the co-ordination of international community.

The ex-President of Pakistan General Musharraf claimed, in 2007 in Kabul, that the people of both the countries Pakistan and Afghanistan faced "A great danger in the shape of Taliban". He suspected that the problem may convert into "A national war by Pashtuns" against all the existing forces in the region including foreigners. He added that regarding the intensity of the Taliban's potential as "centre of gravity of terrorism" shifted from Al-Qaida because they became "more organized". According to his point of view they "Obscuration social concept" Musharraf called Taliban "a particularly forum" of terrorism.

\section{CHINA'S STRETEGY TOWARDS AFGHANISTAN}

The strategy of China didn't remain aliened with the western countries. She delayed offering the armed training to the Afghan government. Later when it was confirmed in 2010, that the Taliban wouldn't be defeated by US China set contacts with Taliban. Many groups of Talibans went to China, which indicates the China's act to strengthen the relations with the groups. This strategy of China increased its reliance not only on Pakistan but on the supporter of Taliban in Pakistan too, for instance, Maulana Sami ul Haq, religious scholar and senator known as the father of the Taliban. Afghan government showed its concern relating often meetings between the groups and China. Further reflected disappointed on the reluctance of China to brief the justification for her 


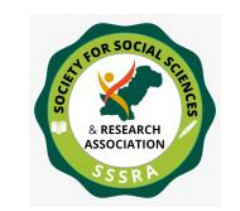

Pak. Journal of Int'L Affairs, Vol 4, Issue 3 (2021)

Overview: Struggle for Islamic Emirate ...

act. For the purpose to activate the the talk with Taliban aiming at the support and stability of Afghanistan.

In 2016, China united a "Quadrilateral Coordination Group" with US, Pakistan and Afghanistan. The purpose of it was to check the Taliban fighters' advancement in the Afghan lands. Later the meeting with taliban indicated the China's denial toward the said "Quadrilateral Coordination Group".

While previously in 1990s China opposed Taliban along with the Northern antiTaliban Alliance, Russia India, Iran and US. Since the presence of foreigner forces present in Afghanistan to solve the problem arose by World Trade Centre attack, China kept herself reluctant from involving in a military presence in Afghanistan. She initiated bilateral military relations with Afghan government. During resent past ears she gave a meager armed support to Afghanistan. In 2016, Chain intended to contribute $\$ 70$ million, for the purpose, in the comparison of US support $\$ 4$ billion. China planned to enhance its armed existence in Afghan lands and intended to deploy its troops in Wakhan Corridor of Badakhshan Province.

Afghan government put that China designs to build a military base for the reason of the area expanded towards China border. Including the offer to provide military trainers to Afghanistan, it wanted to deploy a "people's Liberation Army bridge". The offer was withdrawn after Afghan government request asking Russian helicopters China remained interested for installing its internet system, known as a rival of "American Global Position System (GPS). Keeping in view the possibility of spying on Afghan, US and its allies the Afghan government was reluctant from accepting the offer and annoyed China. Eventually she deployed its military in Tajikistan along the Wakhan Border.

Russia,In March 2010, "China Afghan Strategies and Cooperative Partnership" was concluded and signed. It reflected the desire of the Afghan government to acquire the extensive role of China. President Ghani hoped that the "partnership" was to minimize the intricacy and to moderate the relation with US and counter balance the US pressure.

On the stage of the departure of foreigners including the US forces since April 2021, the Taliban became quite confident for their power establishment in Afghanistan. While the leaders and elders gathering their private maltia indicating civil war on the same footage as it was started after retreating of Russia. Secret meetings and negotiations with Taliban by the tribes multiplied the chances of their ascendancy. The suspected violence, inflow of refugees from Afghanistan and upcoming security challenges, 


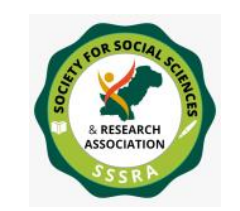

Pak. Journal of Int'L Affairs, Vol 4, Issue 3 (2021)

Overview: Struggle for Islamic Emirate ...

increased the concern of Pakistan. Up till that stage the border issues solving, the ventures through talks proved not much successful.

\section{PAK AFGHAN RELATIONS IN FUTURE}

As far as the question of Pak-Afghan relation is concerned. It civil war, after leaving US forces, prolongs, the development in relations would remain in pending. The Afghan Pakistan Action Plan for Peace and Solidarity still needed to be made effective.

\section{HISTORY OF RUSSIA ATTACK AND RETREAT \& AFTER EFFECTS}

Afghanistan couldn't change much its internal matters and situation. It had tribal battles and civil wars before the Soviet attack. The government was determined to implement reforms to solve, particularly in the matters relating land and the gender based equality in 1978. It deteriorated the situation and tension intensified after torture, arrests and ousting the rivals of the government. It provided an opportunity to to Russia to intervene in 1978. More or less the same situation was repeated when the arrival of international forces occurred. In 1990s there was a scenario of civil war in Afghanistan many groups were active. The US forces left finally but there was civil war behind them in Afghanistan between the government and the Taliban.

The history of foreign occupation in Afghanistan is expanded more than 4 decades taught remarkable lesson vital to design the future political scenario of the region.

a. Afghans are absolutely not tolerant for foreign occupation.

b. There internal affairs cannot be settler forcefully.

c. Their political matter are linked with financial matters.

d. The plus point throughout history from 1933 to 1973, was its potential of survival with meager sources in the state of civil war and even during foreign occupation.

e. A series of earnest efforts were made for tribal reconciliation and establishment of central since 2001 .

f. It's difficult to control regional and local political leaders, who are not ready to obey the rule of law. Quick and extreme reforms met with failure.

A moderate and slow constant may test. The succession problem and clashes for the purpose is a serious issue of Afghanistan. This tradition used to push the state in civil war for long term and repeatedly. Despite of two elections were conduct in 2001, but the transfer of power couldn't done. 


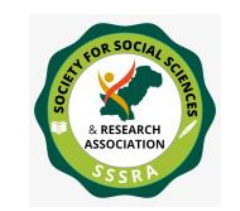

Pak. Journal of Int'L Affairs, Vol 4, Issue 3 (2021)

Overview: Struggle for Islamic Emirate ...

\section{AFTER USA WITHDRAWAL}

As Taliban struggled for the establishment of the Islamic, state and "Sharia" Law, proposals by individuals are being forwarded which not very different from the existing constitution. A Taliban's spokesman urged to implement the Constitution, properly and earnestly. The prevailed laws are in-accordance of "Islamic Sharia Hanfi school of thoughts. According to a farmer. Taliban's minister two types of laws are there:-
a. Constitution
b. Common Law

The first one is far the legal frame work and the other is related to civil laws. As the brief, both type of laws are existing and only needed to be implemented. Islamic laws demand the prohibition of usury and alcohol. The "Hudood Law" are based on the Islamic Penal Code and containing specific and harsh punishments for some crimes. It authorizes the execution of the killer by the family of the killed one, hand's amputation of a thief and stoning to death for adultery. The upholder, of human rights, consider these punishments as the violation of human rights.

\section{FUTURE STATE OF TALIBAN}

Interviews taken by many researchers proves that along with the politicians, even, among common people there is a consensus of opinion for adopting religious practice in the people including the education system and media too. Huge funding for the promotion of madrasas help of ulma with their presence in the national politics.

For the purpose letter, within the areas under the influence of the Taliban, was circulated among the leaders of Taliban, indicating the vital steps required to be taken after the withdrawal of US forces. According to the text of the letter the anti-Islamic, publishers and institutes like Oxford, Cambridge and Agha Khan Education having the curriculum book writing task. The authors of those books are for from Islam. So they producing curriculum having, no link with "Deen". Thus the existing system of education can help to prepare the students, only, eligible for the fields of medical, engineering and art, but with a mental approach alike Americans and the Westerns, unaware of Islamic values and criteria of life. They may think Islam as the religion of past only. The system will cause the shortage of Ulamas. They will see the heroes and conquers of our history like Mehmood Ghusnavi as greedy for extending their lands and powers, and idealize those who found the modern democratic system in Muslim states. An ex minister expressed that with the Afghan cultural context, an Islamic system should be prevailed to promote Islamic values and Afghan cultural side by side. He condemned the simply 


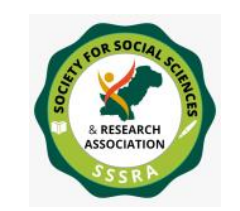

Pak. Journal of Int'L Affairs, Vol 4, Issue 3 (2021)

Overview: Struggle for Islamic Emirate ...

copying the system from any other Muslim country. He coded the example of 'hijab' as it is prevailed in Malaysia or Egypt is not enough for Afghanistan in context to meet it cultural needs. So there is unanimous view print regarding the legitimacy of Islamic Law.

\section{REGIONAL ROLE}

In 2018, the US President Trump approached Pakistan for its assistance for USTaliban talks. In October 2018, US secretary of Defence "expressed gratitude" to his counterpart in Pakistan, for facilitating the Taliban's member to travel to Doha for talks in March 2021, and acknowledged the continuous support in connection of Afghan peace process. Since the Soviet invasion in Afghan in 1979, Pakistan facing problems like over one million Afghan refugees in the country, unresolved Durand line, 1600 mile long border. India not only remained a threat for Pakistan but its involvement diplomatically and commercially in Afghanistan intensity it negative role against Pakistan. As far as matter of the existing relation of Afghanistan with the Ex-Soviet states and the Central Asian neighboring countries, Afghanistan is having warn friendly relations with them. One of the Taliban's step relating Islamisation is the ministery for "Amr Bil Maroof Wa Nahi an al Munkir", assigned the duty to implement the orders and decision accordingly. Music and T.V. was banned. The females wear "Burka" to cover themselves fully from head to toe while they are outside their houses. Even in "Parda" they could not go out without their "Mehrum" 'a male family member'. Beard is compulsory for men. Restricted women to work outside their homes. Previously, before the Taliban's empowerment the women's participation was $40 \%$ in the field of medical, 50 percent in civil services, and more than men in education with a percentage of 70 . Keeping this restrictions many NGOs and UN agencies trained their female employees as health workers to provide the health facility to women. After 2001, Taliban regained power in province Kunduz in 2008. They forbid the people form cooperation with the government's employees/foreigners personnel and any NGO or agencies, were working for the development purpose. But surprisingly, they didn't show restrictions relating Music, T.V., smart phone use and beard for men. After 2005, Taliban expanded the restrictions along with the expand of their possession over Kunduz districts. They adopted the pattern of fast and quick punishment for several crimes.

\section{FEMALE EDUCATION SITUATION}

The number of females in educational institutes increased significantly since 2002, reflecting government efforts and funds from forcing countries. But the results in the areas influenced by the Taliban are not same. There the women contribution to 


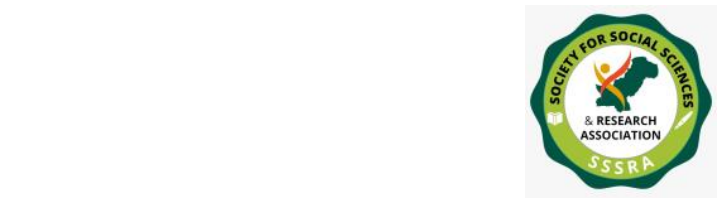

different spheres of life remain limited even if they were under government control. While the active role of female in the rest areas increase noticeably. Their participation increased to the peak with no such example in the history of Afghanistan. But it was again started to drop after 2014, for the reason of increasing insecurity, funding decreased and boasting graph of decreasing. "Community-based education" offered by NGOs in the areas where hurdles like family restriction, communal limits and expanding insurgency confined the girls within their houses. The findings of Human Rights researches shows the desires and demands for female education.

Despite the fact that the Taliban indicated not to oppose the girls' schooling. The fact is the lack of consensus of opinion among the Taliban commanders on the matter. For instance, a teacher in the province of Wrdak said"Today (A Taliban official) tells you they allow girls up to six grade, but tomorrow, when someone else come instead, he might not like girls' education."

Although the majority of Taliban abide by the primary insurance relating equality in the spheres of life including gender, religious freedom, family life religious freedom, family life protection and proper dealing including justified trial according to the Geneva Convention in 1949, Article 3. This practice did not be observed completely. Many on individual level not acting accordingly violate the Article 3 committing war crimes.

The accord concluded between US and the Taliban purpose of the US forces withdrawal from Afghanistan but the matter was clipped with the condition for Taliban not to target IS and her Allies from the Afghan land, to ensure providing basic human rights, freedom of education for women, right to express and freedom of media.

During last ten years China's first increase and decreasing role in Afghanistan was evident her steps remained careful. China's economic interest made her to pay attention the Afghan lands latter it confined its role to consolidate its security in the areas of Xinjiang.

They kept on doing efforts to implement reforms in the field of education with the purpose of the modernization of the system and to accommodate the females to meet the international education and activism criteria and to give them the equal share in all the fields of life from the beginning of the society. To achieve the purpose schools were established for girls. The reforms however were not welcomed in the villages and remote areas received great challenge. They considered it as the steps against the tribal set up and traditional norms. The scarce opportunities are there in the villages to avail educational facilities accept "madrassa" and "Masjid" for females particularly. 


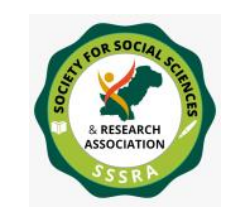

Overview: Struggle for Islamic Emirate ...

The extreme reforms by the government of People's Democratic Party (PDPA), established in 1978, brought severe unrest in the state. The reforms caused the eruption of civil war, violence and massacre. Even the situation provide opportunity for Soviet attack. The international stake involved and Mujaheddin started resistance. They were supported by USA. They, not only, loyal an important role to push back Russian but crushed the PDPA government and retreated their forces. They didn't tolerate school and NGOs, either demolished or burnt to ashes.

In 1991, after leaving the Soviet forces, they adopted the strategy of promoting the education among female. Out of different warrior groups, fighters joined Taliban and proved themselves extremist. Education for females was banned, schools were ceased to work from 1992 to 1995, in the areas occupied by Talibans, particularly in Herat.

The situation was worsen under the Mullah Omer. He hauled the women's and girls' education and this dead lock was lasted up to 2001, when US defeated Taliban. Although the available Constitutional supporting the girls' education, but the infrastructure was destroyed during the continuous wars. To despite the legal support, it is hard to provide education in the prevailed situation. In 2016, on the basis of a report concluded under the US special Inspector General for Afghanistan it was detected that out of appointed teachers, from 20 to 38 percent were ghost teachers, were taking incentives without serving. Different types of schools are there in Afghanistan. The government schools are under the government control, private school confined in the main urban cities serving only the people who can effort its exoendures and fees, madrasa are not the part of the government sector. Madrassas are serving only for religious education and do not meet the curriculum criteria set by the government. So many subjects are not the part of their syllabus. However in any sector either government, private or community, all are mostly private separate. In government universities the coeducation system is prevailed. In 2001, the defect of Taliban by the international forces under the supervision of US, followed by the battles, to gain the power. It was intensified due to the absence of a strong government. Different militant groups targeted girls' schools.

A fresh wave to get the reins of power, Taliban started struggling. They tried to keep the people from supporting the government and to cause terror, targeted the schools in country side to root out the physical presence of the government. During one and half year, from the beginning of 2005 till the mid of 2006, the destruction by the Taliban, occurred against hundreds of school. Taliban were not only responsible for this, but many other armed groups adopted the some style. 


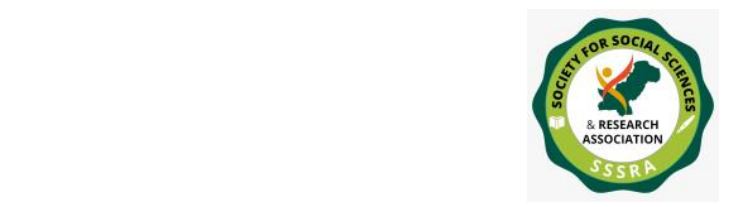

The graph of schools destruction started reducing from 2007, and continued till 2010. The Taliban intended and expressed their intention to safeguard the education. After that the targeting was minimized but could not be stopped completely. Eighteen armed attacked areas demonstrated against the education system including the school, teachers and other employees reflected in the report of the United Nations Assistance Mission in Afghanistan (UNAMA) in 2019.

\section{EDUCATION POLICY \& TALIBAN}

An education policy was formulated by Taliban in 2014. In the schools under their control they brought changes like the priority of the religious education. The teaching relating music, lessons about terrorism and updating history were banned. They terrified the researcher for not paying tax to them. A memorandum of understanding was finalized in the province of Helmand with the following main features.

1. Taliban were to spread the message through Masjids announcing that the education was vital. The school would be considered as the nation's assets and were to be kept from any damage.

2. Government education department on both levels provincial and central would be authorized to visit and inspect the educational institution in the areas under the influence of Taliban.

3. The responsibility was delicate to the education department, regarding the establishment of community-based education in the areas where school couldn't be established till them.

4. To eliminate the hurdles between the both parties meetings would be continued for the purpose of coordination.

5. Despite Qur'an supports the girls' education equally as for male. Taliban mostly opposed it especially the higher education. Even so far minors they stressed that the girls can go to Masjid, madrasas and to private homes only for education instead schools.

Taliban assured their open mindedness relating the female's education on every level including the university, in the talks relating the US forces withdrawal in 2019-1010. Again a reversal from their support to education and in a meeting with Human Rights Watch (HRW) in April 2019, and adopted the point of view that they would not force the community for girls' education who, on the basis of their tribal traditions oppose it.

The sketch of the people's broad mindedness reflects that in Logar, Samangand and Kunduz they allow their girls for education, but on contrary Uruzgan and Helmand 
the people are not ready to send their women to schools. So instead of imposing the female education, they are required to be convinced first.

In the context of the present scenario when US forces are completely withdrew and Taliban got control of the entire country, the people are evacuating from the country shows they seek no survival of them under Taliban's regime. Now the upcoming Taliban policies will decide the fate of the state, the problems and solution including education and of course its impacts on the region. 


\section{REFERNCE:}

Adam. (2013)."A brief History of Afghanistan". A speech delivered at a student against war teach in Duluth,Minnesota(USA).

Amir shah Karmani, M.2004, Afghan ethics, strategic Quarterly, pg31, 96-106.

Bakhshi.J. (2012).The role of Pakistan in the Afghan peace process (Persian translated). International Center for peace studies.

Fukuyama's recent writing on the failure of the new theory conservatives, Journal of Political and economic Information, pg. 207-208.

Ghahrampour.R. (2003), studies of American Isreal.Quarterly journal of regional the Presence of United State in Afghanistan and the National interest of Iran.Pg 4-3.

Hemati.M. (2010).Maybe the Beginning of the Third world War. Tehran Nasser Publisher

Iftikhar.H. (2002)."Pakistan in 2001: The Afghanistan crisis and rediscovery of the Frontline State.pg204-212.Asian Survey.Vol.42.No.1.

John.F. (2009).’Why is Afghanistan so Important”.Laxmi,T.(2017).

Khalili.M. and bahush Fardaghi .M.(2014).comparison of Iran perspective on on American Army strike in Afghanistan, Journal of research political and International Affairs of Shahreza,pg 41-79.

Marsden.P system in Afghanistan. (2000).Taliban, War and religion and the new system in Afghanistan.

Motaghi.E.Zagiri.S \& Jalalian.F. (2009).Terrorism and new Political-Social Movement,pg 261-284.

Shafiei.N,Ataei.S \& Pahlavani.M(2011).The Impact of USA presence on Afghanistan on National Security if Islamic republic of Iran with an emphasis on aggressive realism(2012-2014), Caucasus central Asia.pg. 81-89.

Stanekzal.M(2009).”Dilemmas of State Building in Afghanistan”. World Bank institute development outreach.

Tamana.F. (2008).America Foreign Policy in Afghanistan, Trahan strategic studies institute.

Wright.L.(2006).the Looming Tower. AL-Qaeda and the Road to 9/11(Ist Edition).ISBN:978-1:9781-400-3084-2. 